\title{
HIV-related stigma, asset inheritance and chronic poverty: vulnerability and resilience of widows and caregiving children and youth in Tanzania and Uganda
}

Article

Accepted Version

Article

Evans, R. (2015) HIV-related stigma, asset inheritance and chronic poverty: vulnerability and resilience of widows and caregiving children and youth in Tanzania and Uganda.

Progress in Development Studies, 15 (4). pp. 326-342. ISSN 1477-027X doi: https://doi.org/10.1177/1464993415592740 Available at https://centaur.reading.ac.uk/37818/

It is advisable to refer to the publisher's version if you intend to cite from the work. See Guidance on citing.

To link to this article DOI: http://dx.doi.org/10.1177/1464993415592740

Publisher: Sage

All outputs in CentAUR are protected by Intellectual Property Rights law, including copyright law. Copyright and IPR is retained by the creators or other copyright holders. Terms and conditions for use of this material are defined in the End User Agreement. 


\section{www.reading.ac.uk/centaur}

\section{CentAUR}

Central Archive at the University of Reading

Reading's research outputs online 
Final accepted version of paper in press in Progress in Development Studies

Title: HIV-related stigma, asset inheritance and chronic poverty: vulnerability and resilience of widows and caregiving children and youth in Tanzania and Uganda

Author: Ruth Evans

Department of Geography and Environmental Science, University of Reading

\section{Contact details:}

Dr. Ruth Evans

Associate Professor in Human Geography

Department of Geography and Environmental Science

University of Reading

Whiteknights PO Box 227

Reading RG6 6AB

UK.

Email: R.Evans@ reading.ac.uk.

Tel. +44 (0)118378 7755 . 


\section{Abstract (100 words)}

This paper develops a framework of risk and protective factors to conceptualise the relationship between HIV-related stigma, asset inheritance and chronic poverty among widows and caregiving children and youth in eastern Africa. Analysis of two qualitative studies with 85 participants in rural and urban areas of Tanzania and Uganda reveals that gendered and generational inequalities and stigmatisation sometimes led to property grabbing and chronic poverty. Human and social capital and preventative measures however may help widows and caregiving young people in HIV-affected households to safeguard land and other assets, within a wider supportive environment that seeks to tackle structural inequalities.

\section{Key words}

Risk and resilience

Asset inheritance and disinheritance

Chronic poverty

HIV stigma

Widows and caregiving children and young people

Tanzania and Uganda 


\section{Introduction}

Land and property are central to people's livelihoods and security in many Sub-Saharan African countries (Odgaard, 2002; Ellis and Mdoe, 2003). The HIV epidemic in Eastern and Southern Africa has exacerbated chronic poverty and gender and generational inequalities in access to land, property and other assets (Drimie, 2003; Seeley, 2008; Hulme and Shepherd, 2003). Women living with HIV may experience multiple forms of stigma and discrimination, including property grabbing and asset loss (Evans and Becker, 2009; Muyinda et al, 1997; Walsh, 2005). Widows with HIV may be blamed for the death of their husbands because of relatives' assumptions that they 'brought' the disease into the family and/or used witchcraft against their husband and their children (Ogden and Nyblade, 2005). Widows living with HIV and orphaned young people thus appear to occupy a weak bargaining position in safeguarding asset inheritance following the death of male heads of household. Evidence on the relationship between HIV and disinheritance, however, is very limited. As Cooper (2010:13) comments, 'While many policy analysts are concerned about the inter-related risks of property disinheritance and HIV/AIDS, how the two affect each other is not yet well understood'.

In this paper, I seek to provide insight into how HIV-related stigma, asset inheritance and chronic poverty may be related. Drawing on two qualitative datasets with 85 participants from Tanzania and Uganda, I develop a conceptual framework of risk and protective factors that influence vulnerability and resilience to stigma, disinheritance and chronic poverty in communities affected by the advanced HIV epidemics in eastern Africa ${ }^{1}$. I analyse gendered and generational vulnerabilities among widows and caregiving young people, in addition to resilience and protective factors that helped some households to safeguard asset inheritance and avoid chronic poverty. 


\section{Widows' and caregiving young people's access to land and other assets in Africa}

Land tenure systems and customary inheritance practices vary according to socio-cultural norms, colonial legacies of land settlement and allocation processes and the wider legal, religious, and political context in different African countries (Joireman, 2008). While both patrilineal and matrilineal inheritance practices are observed in Eastern and Southern Africa, this paper focuses on study locations in Uganda and Tanzania where patrilocal and patrilineal practices predominated. Although customary norms differ according to locality and ethnicity, within patrilineal inheritance systems, women usually leave their natal homes when they marry and gain usufrust rights to land and property through their husband's family (Tripp, 2004). Land inheritance is the key means for the intergenerational transfer of wealth in rural areas (Cooper, 2012) and in patrilineal societies, the eldest sons are usually the main heirs, while in matrilineal societies, heirs are usually male maternal relatives. Separated or divorced women often have few rights to the family home, land or jointly acquired assets and widows may lose assets, which are traditionally held in trust for their children, to their husband's relatives after his death (Bird and Espey, 2010).

A growing literature has identified the negative impacts of gender discrimination on women's access to assets (Deere and Doss, 2006). Assets such as land, financial capital and property are associated with higher status and increased bargaining capacity in intra-household resource negotiations. If women have less bargaining power, this in turn often has negative impacts on household expenditure on food, health, education and welfare of children, especially girls (Deere and Doss, 2006). Furthermore, in rural areas, women's lack of ownership and control over land and agricultural management has been shown to constrain agricultural productivity and weaken household consumption and nutrition (Jones et al., 2010). 
Some studies suggest that disinheritance and asset stripping of women, particularly widows, is becoming increasingly common in Eastern and Southern Africa in recent years (Walsh, 2005; Izumi, 2007). Women with HIV whose husbands have died of AIDS-related illness may be more likely to experience property grabbing and asset stripping than other widows, often leading to impoverishment (Mendenhall et al., 2007; Walsh, 2005). Aliber and Walker (2006) suggest that HIV can aggravate the vulnerability of certain groups, particularly widows, to land tenure loss in Kenya and conclude that HIV affects a person's social capital, which hinders their ability to gain support from community members and leaders against a threat to their tenure.

Although practices by ethnic group, in patrilineal societies, under customary law, when a father dies, his land, property and other assets are usually held in trust for sons (and sometimes daughters) until they are considered mature enough to manage inherited assets (Tripp, 2004). Although little research has focused explicitly on asset inheritance among young people, studies suggest that orphaned children's inheritance rights to land and property may be denied following their parents' death (Van Blerk et al., 2008). Drawing on case studies from HIV-affected communities in Rwanda, Lesotho, Kenya and South Africa, Rose (2007) and Drimie (2003) argue that relatives may confiscate the deceased parents' land and refuse to relinquish it to orphaned children when they reach the age of majority. Children's low status in generational hierarchies means that they are rarely involved in decision-making processes about inheritance and use of family assets, and orphaned young people may find it very difficult to regain access to their deceased parents' land and other assets once confiscated (Rose, 2007). Widows in polygamous unions and children whose fathers engaged in polygynous relationships may occupy a particularly marginal position; particular wives, such as those 'officially' married in church or the mosque, and their children may be vulnerability and resilience of widows and caregiving children and youth in Tanzania and Uganda, Progress in Development Studies. 
prioritised over other co-wives and their children (Seeley, 2012) and may be regarded as having a greater claim to the husband's/father's assets following his death.

The land rights of widows and orphaned children are further undermined by wider institutional and legal discrimination, such as Land Acts and community regulations about land use which differ according to country and locality (Drimie, 2003; Rose, 2007). Progress has been made in legal reforms to prohibit discrimination and address women's property and inheritance rights following in several African countries, including Tanzania and Uganda, in recent years (Cooper, 2012). The customary tenure system predominates in Uganda and provides for both individual and communal land ownership which is regulated by customary rules often administered by clan leaders (Tripp, 2004). In this system, land is not generally titled or registered. Women activists lobbied to ensure that the 1995 Ugandan Constitution and the 1998 Land Act protected women's land rights; for example, the Act prohibits decisions pertaining to customary land that deny women access to, ownership of, or occupation of land (ibid). Similarly, in Tanzania, radical legal reforms shifted land tenure administration to the elected government of each village (Tripp, 2004). Women are granted the same rights as men in the Constitution and in the 1999 Land Acts (Odgaard, 2002). The Land Act overrides customary law if it denies women their right to use, transfer and own land and women's rights of co-occupancy are also protected (Tripp, 2004).

The introduction of privatised land ownership systems in several African countries have in some instances hindered rather than facilitated women's access to land (Tripp, 2004; Whitehead and Tsikata, 2003). The costs, bureaucracy and poor governance represent additional barriers. Furthermore, if land is unused and/or underused, relatives or neighbours may take it over, or when local authorities are informed of the underuse of land, they may assign it to others (Odgaard, 2002; vulnerability and resilience of widows and caregiving children and youth in Tanzania and Uganda, Progress in Development Studies. 
Rose, 2007). Since households headed by widows with HIV, grandparents and orphaned young people struggle to secure sufficient agricultural labour to cultivate land, they are at risk of losing access to this vital asset that they rely on for food security (Rose, 2007) and a future stream of benefits.

\section{The research}

Tanzania and Uganda have been severely affected by the HIV epidemic since the 1980s and an estimated 1.5 million people of all ages were living with HIV in each country in 2012 (UNAIDS, 2013). At the time of the research in 2009, an estimated cumulative total of 1.3 million children (aged 0-17 years) in Tanzania had lost one or both parents to AIDS; in Uganda, the figure was 1.2 million children (UNAIDS, 2010). This paper analyses the findings of two qualitative studies that investigated young people's caring responsibilities in families affected by HIV in Tanzania and Uganda. Almost all of the caregiving young people interviewed can be defined as 'orphans' (UNAIDS, 2010), since they had lost one or both parents to AIDS, although this terminology glosses over the differing situations of 'double orphans' whose parents have both died, 'single orphans' who live with a surviving parent, those live in child- or youth-headed or grandparentheaded households and so on. Qualitative methodologies are considered particularly appropriate for investigating the experiences of marginalised groups and analysing the wider social and institutional context of their lives. Although not the primary focus of the studies, inheritance and access to assets emerged as significant themes in both studies.

Due to the hidden nature of young people's care work, purposive sampling techniques were used to recruit participants through NGOs supporting HIV-affected families from regions in Tanzania and Uganda with high levels of HIV prevalence and orphanhood. A key criteria for selection of 
participants was that HIV or AIDS had been recognised either medically or by organisations working with family members. This may have resulted in an atypical sample of particularly vulnerable families, currently or recently accessing services and support from community-based NGOs. The difficulties in gaining access to this group, in addition to ethical considerations about the potential vulnerability of participants, made this approach necessary. In practice, some of the caregiving young people, especially those in Uganda, received very little or no support from the organisations that identified them for the study. Thus, the sample reflects a diverse range of experience in accessing NGO support.

In the first study in Tanzania (2006-7), semi-structured interviews were conducted with 20 mothers/female relatives living with HIV and one guardian; 22 young people (aged 11-24) who cared for a parent/relative with HIV; and 13 support workers from seven NGOs in four regions: Arusha and Kilimanjaro (rural) and Dar es Salaam, Mererani, Manyara region and Moshi, Kilimanjaro region (urban). Most women living with HIV interviewed (16 of 20) had been widowed or had lost at least one male partner due to AIDS-related illness before antiretroviral therapy (ART) became available free of charge in 2005.

In the second study (2008-9), a small purposive sample of orphaned young people who cared for their siblings without a co-resident adult was identified through NGOs in rural and urban areas of Tanzania (Nshamba, Kagera region, Dar es Salaam and Mbeya) and Uganda (Kampala and Mpigi, Mukono, Wakiso and Luwero districts, Central region). Semi-structured interviews were conducted with 13 young people (nine young women, five young men, aged 12 - 23) from eight child-headed households and three youth-headed households; one grandmother and one young woman caring for her in a skipped generation household; and 15 project workers from five organisations. All the vulnerability and resilience of widows and caregiving children and youth in Tanzania and Uganda, Progress in Development Studies. 
young people interviewed were 'double' orphans, whom NGO staff confirmed had lost both their parents to AIDS in recent years. Following data analysis, participatory feedback workshops were held in the three main research locations of Kampala, Mbeya and Nshamba with 33 young people (15 siblings heading households and 18 of their younger siblings) and 39 NGO workers and community members.

Interviews and focus groups in Tanzania were conducted in Kiswahili and transcribed and translated into English with research assistance. In Uganda, interviews were conducted in English with interpretation to/from Luganda provided by NGO workers, although some young people spoke English. Individuals' accounts and research locations have been anonymised to protect participants' identities. The interview transcripts were reviewed and an analytic summary was developed informed by Bolt and Bird's (2003) Vulnerability and Capacity Analysis Tool and the Sustainable Livelihoods Framework (Chambers and Conway, 1992). Visual data and interviews with NGO workers were thematically analysed.

The datasets comprised a diverse range of household structures and access to physical assets. The majority of households were located in rural areas (21 of the total of 35 households). In the second study, seven households were located in Uganda and five in Tanzania. Despite commonalities in patrilineal inheritance systems in Tanzania and Uganda, the study locations differ to some extent in terms of socio-cultural practices, availability of external support and livelihood options in rural/urban areas. Young people heading households in Tanzania and Uganda shared common experiences which contrasted with the situation of children caring for their mother/relative with HIV in Tanzania, although their experiences differed in terms of access to external support. These qualitative samples do not aim to be representative, but rather provide insight into the processes and 
factors that influenced widows' and caregiving young people's vulnerability and resilience to HIVrelated stigma, asset inheritance and chronic poverty in rural and urban communities affected by HIV in Tanzania and Uganda. Following an overview of the conceptual framework developed, I analyse women's and young people's experiences across the two datasets and explore in more depth some of their critical lifecourse transitions over time.

\section{Conceptual framework}

This paper adopts a lifecourse perspective that explores changing access to assets over time and uses a gendered and generational lens to analyse the relationship between HIV-related stigma, asset inheritance and chronic poverty. Commentators have critiqued the compartmentalisation of research on younger and older people and highlighted the importance of intergenerational and lifecourse perspectives (Vanderbeck, 2007; Hopkins and Pain, 2007). A key defining feature of 'chronic poverty' is its extended duration; people who experience 'significant deprivations for a period of five years or more' are more likely to remain poor for much of their lifecourse and 'pass on' their poverty to subsequent generations (Hulme and Shepherd, 2003: 405). Commentators have called for greater understanding of the risk and protective factors that mediate poverty outcomes (Boyden with Cooper, 2007) and identified a need to analyse key moments of transition in the lifecourse, in addition to household and intra-household factors (Bird and Higgins, 2011).

Ownership of physical assets and positive transfers of resources appear to break poverty cycles (Cooper, 2012). As Bird (2011: 3) notes, 'assets (particularly land) are a key determinant of nonlabour income and can enable the diversification of livelihood options, provide collateral for formal sector borrowing, enable investment (including in human capital formation), reduce vulnerability, boost resilience and limit the need to adopt adverse coping strategies'. Seeley (2008: 48) argues 
that, in the context of the HIV epidemic in Uganda, poverty is not 'transmitted' from one generation to the next so much as 'recreated' due to structural factors that constrain opportunities to build assets and develop sustainable livelihoods. Following the sustainable livelihoods framework (Chambers and Conway, 1992), assets have been conceptualised as different forms of capital, including physical assets and material resources, such as land, livestock and property, and human, financial, socio-political and environmental capital. Inheritance represents a critical mode for the transfer of property and other assets between generations (Cooper, 2012).

Studies have demonstrated the significance of people's social location and the support they are able to draw on within an ethnic group, family/clan, marriage, friendship, patron-client relations, relations with authorities at various levels of society in gaining access to assets, particularly regarding claims to land under customary tenure (Odgaard, 2002; Whitehead and Tsikata, 2003). Although 'social capital' is a contested concept (Radcliffe, 2006), in this paper, the term is used to refer to social relations, ties and networks that people draw on for support and opportunities for participation, which are underpinned by power relations and inequalities of gender, age, ethnicity, religion and other axes of social difference. In addition, education is regarded as a key factor in building human capital and empowering young people, particularly girls, to understand their rights and entitlements as a means of reducing the likelihood that they experience chronic poverty (Harper et al., 2003; Kabeer, 2000). Reduced access to education means that children may not receive investment in their education and welfare, limiting their human capital and their life-long earning capacities. This often has negative effects on their health and wellbeing over the lifecourse.

Common causes, forms and consequences of HIV-related stigma have been identified across many different sociocultural contexts (Ogden and Nyblade, 2005). Stigma by association may affect vulnerability and resilience of widows and caregiving children and youth in Tanzania and Uganda, Progress in Development Studies. 
caregivers just as much as people living with HIV themselves (Evans and Becker, 2009). Orphaned children and elderly relatives living in youth-headed and skipped generation households, where parents have died of AIDS-related illness, may experience exploitation and asset loss due to stigma by association (Thurman et al., 2008). Although Goffman's [1963] classic work on stigma has been very influential, Parker and Aggleton (2007: 450) argue that stigmatisation and discrimination need to be understood not just as affecting individuals, but rather as 'social processes inherently linked to the production and reproduction of structural inequalities'.

Despite the negative impacts of HIV-related stigma and chronic poverty, men, women and children are social actors who constantly adapt to their circumstances, manage vulnerabilities and often diversify their livelihood strategies in order to break the cycle of poverty in both rural and urban environments (Seeley, 2008). The concept of resilience emphasises people's strengths in coping with adversity and their agency in engaging with protective factors that may help to reduce their vulnerability (Rutter, 1990; Schoon, 2006). Protective factors are however likely to be contextspecific and to vary cross-culturally (Schoon, 2006; Ungar, 2004).

Based on analysis of the two datasets and the literature, this paper develops a conceptual framework of resilience and vulnerability, alongside analysis of gender and generational relations, to show how a dynamic combination of interrelated factors and processes influence the vulnerability and resilience of widows and caregiving young people to HIV-related stigma, discriminatory inheritance practices and chronic poverty at the individual, household and community levels (see Figure 1). Protective factors that help to safeguard inheritance and prevent chronic poverty are identified on the upper half of the framework, while risk factors that lead to disinheritance, asset loss and chronic poverty are identified on the lower half of the framework. The vulnerability and resilience of widows and caregiving children and youth in Tanzania and Uganda, Progress in Development Studies. 
different dimensions of the framework are not intended to imply causal relationships between different types of capital, but rather, as the arrows indicate, these elements may combine, accumulate and lead to positive or negative outcomes.

The literature on risk and resilience (Rutter, 1990; Schoon, 2006; Boyden with Cooper, 2007), combined with the empirical findings from the two datasets, suggest that it is the accumulation of risk factors that may ultimately lead to disinheritance, loss of access to assets and chronic poverty, or alternatively, the accumulation of protective factors that may lead to asset inheritance and resilience to chronic poverty. The examples given under each heading do not represent an exhaustive list, but summarise the research findings discussed in this article. The following sections analyse how these different risk and protective factors are negotiated at critical moments in the lives of widows and caregiving young people.

INSERT FIGURE 1 HERE

\section{Changing care and inheritance practices within families and communities affected by advanced HIV epidemics in eastern Africa}

Many NGO workers in Tanzania and Uganda thought that conventional patterns of care and inheritance practices had changed significantly in recent years due to the long-term impacts of HIV on families and communities. Traditionally, within patrilineal societies, orphaned children would be divided between different paternal relatives following their father's death (Omari and Mbilinyi, 1997). Paternal relatives appeared increasingly unable or unwilling to fulfil these kinship responsibilities, owing to poverty and to the scale of orphanhood in Tanzania and Uganda. This resulted in maternal relatives, particularly grandmothers, playing an important role in supporting 
widows and orphaned children, as other research in eastern Africa has found (Nyambedha et al., 2003; Oleke et al., 2005; de Klerk, 2011). Indeed, evidence from 21 African countries, including those with high and low HIV prevalence, suggests that there has been a shift towards grandparents taking an increased childcare responsibility in recent years, especially where orphan rates are growing rapidly (Beegle et al., 2010). Research suggests these changing patterns of care in the context of the HIV epidemic in eastern Africa have also led to an increase in young people's care work for younger siblings, parents (especially mothers) living with HIV, older grandparents and other relatives and neighbours with care needs (Skovdal, 2011; Evans and Becker, 2009; Evans, 2011).

Project workers in Uganda explained that most people did not usually make a written will but rather bequeathed their property verbally to family members. As Wood et al. (2006) note, preparing for death goes against the cultural norms of many African societies, and writing a will is often considered to risk bringing misfortune and premature death. However, verbal wills may cause difficulties for widows and orphaned children, as family members and neighbours who claim they have been told different information about the inheritance could exploit their vulnerable position. NGO staff commented that few relatives or local leaders supported the bereaved family with planning for the future care of the children as they used to. Family elders were not as respected as in the past, and this is linked to conflicting worldviews between the generations and the changing value accorded to children's education over time (Stambach, 2000; Kabeer, 2000). Project workers in Uganda suggested that relatives were increasingly motivated to look after orphaned children only if this enabled them to gain access to inherited assets or NGO assistance.

\section{Vulnerabilities of widow-headed households}


Most of the women with HIV interviewed in Tanzania occupied a vulnerable socio-economic position due to stigmatisation and gender discrimination in inheritance practices. Customary norms that restrict widows' inheritance of their deceased husband's assets and the fact that assets had often been sold as the household economy declined during parents' chronic illness meant that women owned few, if any physical assets. Over half (7 of 13) of the one-parent-households of mothers with HIV and their children and two extended-family-households lived in poor quality rented housing, predominantly in urban areas. Many mothers had lived in rented accommodation with their children before their husband/ partner's death or were separated from their partner and had moved several times between rented rooms as they became ill and struggled to pay the rent. They experienced a high level of insecurity and feared eviction, due to a lack of regular income. They were concerned about how their children would cope without them in the future and wished that they could leave a house for them to inherit.

The chronic poverty that mothers and their children faced in Tanzania was often linked to HIVrelated stigma, manifested in harassment and verbal abuse from landlords, abandonment by their husband/male partner, relatives' refusal to provide care or support for the family and property grabbing and disinheritance. Women tend to be both more heavily stigmatised than men because of the association of HIV with judgements about sexual morality, as well as being blamed more often for 'bringing' HIV into a family or marriage (Ogden and Nyblade, 2005). Four households headed by widows were stripped of their property and other assets by the extended family following their husband's death. This loss of assets was linked to HIV-related stigma and the exploitation of customary law inheritance practices that discriminate against widows and children. In all four cases, the late husband's relatives had appropriated the property, financial assets and belongings, as the assets were regarded as belonging to his clan. Physical and financial assets taken from women 
included their home, agricultural land, the husband's pension, business equipment and building materials.

Ester who lived with her sons (aged 12 and 16) in rented accommodation in Moshi town, Tanzania, explained how her husband's relatives sold his land, confiscated his business assets and their shared belongings and withdrew his pension, leaving her in a very vulnerable position, struggling to provide for her children:

When he died we were living in a rented house. Before he died, he was running a hairdresser's salon of his own, after he died his relatives tried to run it but they couldn't pay the rent and electricity bills. It closed down. They then took all the shaving equipment, three rotating chairs and two radios. They took away the TV and a fan from our house, and they sold the farm. I was left with nothing. Then they started drawing his pension money, by the time I realized most of it was gone. I was left with very little. No one is helping me and worst of all I have to look after all the children on my own. Then I also became poorly and I can't manage to look after the children now, we barely survive.

Such a loss of assets was detrimental to widows' and their children's immediate and long-term health and security, and often led to chronic poverty.

Several women in Tanzania decided to move back to their natal families in rural areas in order to reduce the poverty they experienced and gain access to material and care resources through extended family support. Such a move could be heavily stigmatised. Happy (aged 12) who cared for her mother commented on the way that the community blamed the family for bringing AIDS with 
them from town: “They say, 'Why did you bring us this problem?' [..] I say, 'Don't talk like that because I don't know who brought it'”, This illustrates how women living with HIV and their children are constructed as 'vectors' of the disease (Muyinda et al., 1997) and are stigmatised due to notions of contamination, blame and shame. This supports de Klerk's (2011, p110) finding that despite having witnessed the impacts of an advanced HIV epidemic, older men and women in rural Kagera region of Tanzania saw AIDS as a "disease of sexuality, something that belongs to 'those who go in those ways'".

\section{Vulnerabilities of child- and youth-headed households}

Many young people heading households in Uganda experienced a higher level of poverty than the young people interviewed in Tanzania due to limited access to educational and material support from NGOs or other external sources. In Uganda, many were unable to continue with primary or secondary schooling due to poverty and the need to provide for their siblings. While the caregiving responsibilities of some young people heading households in Tanzania had resulted in poor educational outcomes, most received educational support from NGOs at the time of the interview. This difference is also related to the sampling strategy, whereby I was working with NGOs which had a higher level of resources allocated to work with orphans and vulnerable children in Tanzania compared to those working in Uganda, and the most vulnerable child- and youth-headed households were prioritised for support and identified to participate in the research. In Tanzania, however, a minority (estimated 4 to 6 percent) of orphans and vulnerable children receive external support (MHSW, 2006); in Uganda, the figure is just under 11 percent (UBOS and Macro International Inc., 2006). This is consistent with the overall estimate that only a minority (10 percent) of orphaned and vulnerable children who are in need of support are able to access external support in Sub-Saharan African countries (UNICEF, 2006). 
Almost all of the child- and youth-headed households in the study had inherited or had usufruct rights to their late parents' home and land which they could cultivate for food production. Three young people saw their transition to caring for their siblings as a shared decision to stay together and safeguard their inherited land and property. Their decisions were underpinned by a fear of relatives and/or neighbours appropriating their land if they moved away to live with relatives and concerns about fitting into new routines and being mistreated within foster households. Rickson (aged 19) who cared for his three younger siblings in a village in Kagera region was worried about losing their property and was advised by a neighbour to stay and protect their assets. Rickson was also concerned about how they would be treated in a relative's home, highlighting his sister's sexual vulnerability:

We have a farm, although we will not be able to meet all our needs, but it is better we live here alone than going to stay with someone else because if we go to stay with someone we might suffer more. My sister could even get raped; you know staying with others is not the same as staying by yourselves. So I had to decide to look after them. [...] I was convinced we should stay there. I said that I can't leave, I will stay there, to guard our things, our assets, because if I leave, things will be destroyed. So, after three weeks, my aunt left and we were left alone. We stayed there until now.

Such fears about property grabbing, sexual violence and harassment were not unfounded. A third of the sibling-headed households (4 of the 12) had experienced a loss of some assets due to appropriation by relatives. Following their parents' death, some family members (particularly paternal aunts and uncles) exploited unequal adult-child power relations, denied caregiving 
children's rights to inherited land and financial assets and ostracised them. Two young people caring for their younger siblings in Uganda had inherited property adjacent to their home which was rented to tenants. However, their weak socio-economic bargaining position as young people living alone without a co-resident adult made it difficult for them to secure the rental income from tenants or to retain the income for their own use to support themselves. Such experiences of rental income being appropriated by relatives and neighbours in urban areas has also been identified in research with child-headed households in Rwanda (Rose, 2007).

Although young people heading households did not appear to experience such intense stigma by association as young people caring for relatives with HIV, many had direct experiences of hurtful gossip and harassment from neighbours and community members. This was linked to their status as orphans living in their own home without adult supervision, to the poverty they experienced and assumptions that their parents had died of AIDS. In some instances in Tanzania, community members resented the fact that caregiving siblings were able to access NGO support and continue their education, confirming previous research findings (Thurman et al. 2008).

\section{Intersecting gendered and generational vulnerabilities}

Some HIV-affected households appeared to be particularly vulnerable to chronic poverty, due to the intersection of unequal gender and generational relations. Due to patrilocal marriage practices, households headed by young women were regarded by participants in Tanzania and Uganda as being more vulnerable to property grabbing than households headed by young men, who had a greater claim to the inheritance as the sons and heirs. In addition, young women heading households and living alone with their siblings experienced physical insecurity and were 
particularly vulnerable to rape, sexual harassment and exploitation. This led to unwanted pregnancies and the risk of exposure to HIV and other sexually transmitted infections. Three young women heading households interviewed in Tanzania and Uganda had become mothers since they started caring for their siblings, which led to an increase in their care work and further stigmatisation, as young unmarried mothers. As Ringsted (2008) observes, young women who have children outside of marriage are not necessarily regarded as respected mothers and accorded adult status. In the young women's experiences, the biological fathers did not recognise their paternity or consider the children to be affiliated to their family, and hence they did not provide maintenance for their children. Young women heading households who became pregnant could thus be particularly vulnerable to becoming trapped in a cycle of poverty that also affected their children.

Gendered and generational inequalities intersect at critical moments in the lifecourse and constrain the capacities of older and young women to safeguard access to physical assets and escape chronic poverty, as the following example shows. Diana lived with her grandmother and five younger siblings and cousins (aged 8-14) in their house in a village in the Central region of Uganda at the time of the interview. The grandmother had three children, two of whom died in the conflict in northern Uganda. Her last son was in the army and used to send her remittances, which she used to pay workers to cultivate their land, until he died from AIDS-related illness two years previously. Diana studied until the fourth year of secondary school, but had not obtained her school leaving certificate because the family lacked the funds for her to complete her studies following her uncle's death. She worked on the farm with her younger siblings, cultivating cassava, maize, beans, bananas and sweet potatoes for food consumption and her brother milked the cow. Their only income (around 1,000 Ush ${ }^{1}$ a day) came from the sale of milk. Diana cared for her younger siblings

\footnotetext{
${ }^{1} 1$ US \$ was roughly equivalent to 1660 Ugandan Shillings at the time of the interviews in 2008. 20

CRuth Evans 13/10/14. Please cite as: Evans R. (in press) HIV-related stigma, inheritance and chronic poverty: the vulnerability and resilience of widows and caregiving children and youth in Tanzania and Uganda, Progress in Development Studies.
} 
and her grandmother, who had TB, ulcers, high blood pressure and limited mobility. Diana reported that she had few friends, as she needed to stay close to her grandmother to care for her. Diana struggled to pay for the children's school uniforms and shoes, their house was in poor condition and the children frequently became ill, especially in the rainy season. She felt bad about the way that people stigmatised and laughed at them because they were orphans and had nothing to live on.

Samuels and Wells (2009) note that not all skipped generation households are equally vulnerable. They identify the health status of older carers, their age as well as the number of children in their care as key factors which impact on their livelihood chances and the household's capacity to survive. In the case of Diana and her grandmother, access to land was crucial in ensuring food security and the survival of the household. Following the death of her son and the loss of the grandmother's land title deeds in a storm, the son of the original landowner later refused to recognise her claim to the land and sold most of the plot of land which the family depended on for food security. Limited human capital, due to the absence of an economically active 'middle generation', the young age of the children and the frailty of the grandmother, made the underutilisation of the land likely and increased the risk of losing access to the remaining land.

By the workshop stage of the research in 2009, project workers reported that Diana had become pregnant as a result of rape and had given birth and the grandmother had died, so Diana looked after her baby and siblings alone. This reveals the heightened risks of sexual violence and physical insecurity that caregiving young women may be exposed to when heading households alone. Aside from the significant impacts these traumatic experiences are likely to have had on her emotional wellbeing, Diana's gender, age and low social status as a young unmarried mother heading the 
household increased the risk that their precarious usufruct rights to the land could be lost or exploited. Stigma, harassment and marginalisation in the community weakened Diana's social capital and ability to secure support from community leaders, relatives, neighbours and peers to advocate for their land rights. The limited human capital, in terms of the household labour available to cultivate the land, the siblings' constraints in accessing education and the large number of young dependent children, including a baby, heightened the vulnerability of the household to food insecurity and chronic poverty.

\section{Resilience and protective factors}

Half of the young people heading households who had inherited land and property demonstrated considerable resilience in sustaining their households independently, drawing on a range of material and emotional resources, human and social capital and external support (Evans, 2012). Despite negative experiences of stigmatisation and harassment, many young people developed strong social ties with their peers, extended family members, neighbours, community and faith leaders and NGOs, whom they relied on for material and emotional support and protection. Many young people heading households in Tanzania received educational support and some also received regular cash transfers from NGOs at the time of the interview. Community leaders and support workers sometimes played important roles in advocating for caregiving young people's inheritance rights in the study communities, although none of the young people reported direct experiences of this.

Almost a third of women living with HIV (7 of the 23 households) interviewed in Tanzania had usufruct rights to their husband's or other male relative's property until their children reached the age of majority. Many of these households were characterised by chronic poverty and had very limited control of physical assets. However, a small number of widows had managed to safeguard 
their inheritance and/or accumulate assets such as land, livestock and other resources which helped to prevent chronic poverty.

The following example reveals how inheritance practices may challenge conventional gender norms, which, in addition to aspects of human and social capital, helps to build widows' and caregiving young people's resilience to chronic poverty. Husna used to live with her husband, who was an engineer and four daughters in Mwanza, Tanzania. Following his death, Husna and her daughters moved to live with her father-in-law in a village in Kilimanjaro region, where she worked on his coffee and banana farm (he controlled the income from the sale of coffee and bananas) and cultivated maize for household consumption and for sale (which provided an income for Husna and her daughters) on a cleared plot in the bush. Her father-in-law had agreed that Husna and her daughters should inherit the farm when he died. Husna was concerned that her daughters might lose the land bequeathed to them in future. She felt strongly that education was important in building her daughters' capacity to defend their inheritance rights:

So in case things change in the future - that is why education for my female children is good, it will be better if they will have enough education so that in case something happens to violate their rights they will be able to defend themselves. They will be able to say that this is ours, but without education you may be able to say such things but nobody will understand you. If they went to school and understood better they will be able to stand up for their rights.

This reflects Kabeer's (2000: 474) argument that education is not seen so much as a right in itself, but as 'a guarantor of rights, a precondition for the realization of other rights'. Education may help 
to build young women's sense of empowerment and capabilities to resist violations of their inheritance rights, in addition to according them more authority and social status in the community.

This and other examples of Chagga families in Tanzania suggest that widows' social capital, in terms of the supportive relations they may develop with their father-in-law and other male relatives, helped to safeguard inheritance and prevent poverty being passed on to the next generation. Older widows were able to build their social capital through working on their father-in-law's/husband's land in the village over many years, which was respected within the community. Research from several Sub-Saharan African countries suggests that younger widows are more vulnerable in terms of land tenure security than older widows because they have had less time to build relationships with their husband's family (Aliber and Walker, 2006; Cooper, 2012; Peterman, 2012). Widows' social capital and preventative measures to safeguard inheritance, such as writing a will, in addition to the absence of surviving male relatives who might pose a threat to their inheritance, all appear to help to safeguard women's and children's asset inheritance.

It is also noteworthy that the husband's families in these examples belong to the Chagga ethnic group, who have a long history of embracing education, since missionaries first settled on the slopes of Mount Kilimanjaro. Although sons usually inherit banana groves from their fathers, Stambach (2000) argues that perceptions of women's strength and their social status was often related to the many long days they worked in the grove. The inheritance of education was increasingly regarded in the same way as the inheritance of the banana grove, that is, that it connected people to their ancestors and was something which could not be taken away from them (ibid). Women and men thus appeared to be particularly aware of, and receptive to, efforts to promote women's education, empowerment and land inheritance in this locality. vulnerability and resilience of widows and caregiving children and youth in Tanzania and Uganda, Progress in Development Studies. 


\section{Conclusion}

This paper has demonstrated the relevance of a vulnerability and resilience framework, combined with analysis of gender and generational relations, in conceptualising the links between HIV-related stigma, asset inheritance and chronic poverty in communities affected by advanced HIV epidemics in Uganda and Tanzania (see Figure 1). Widows and caregiving young people in Tanzania who received regular financial and/or material support from NGOs emphasised the difference this made to their lives, reducing the pressure on them to earn a livelihood and enabling young people to continue their education and/or pursue vocational training. Young people who lacked such external support in Uganda, in contrast, appeared more likely to drop out of school at a young age, to work long hours to earn enough money to support themselves and their siblings and to experience chronic poverty.

Despite access to ART in recent years, HIV-related stigma continued to have negative impacts on the lives of widows and caregiving young people in Tanzania and Uganda at the time of the research. Stigma was based on multiple processes of 'othering' that reproduced difference and women's and young people's low social status within patriarchal lineage systems. Such processes made it difficult for women and young people to build social capital to help safeguard access to land and other assets and to make the necessary investments in the younger generation, in terms of care and education. These vulnerable households often had weak social ties and held insecure usufruct rights to land that could be exploited by relatives and neighbours. The loss of access to land in rural areas could lead to hunger and food insecurity, poor health and nutritional status, loss of livelihood and a future stream of benefits. Assumptions that the death of a husband or parents was due to AIDS-related illness mean that surviving widows and orphaned youth are more likely to 
be marked out as living with HIV than other groups and to continue to be stigmatised in the era of ART (Roura et al, 2009).

Widows and caregiving children and youth affected by the HIV epidemic may be able to escape chronic poverty through efforts to tackle structural inequalities, provide material support and build their capabilities and skills, which may lead to greater empowerment, participation in decisionmaking processes and control over their lives. The fact that a minority of the widows and caregiving youth in the sample had experienced property grabbing and disinheritance supports Aliber and Walker's (2006) findings that asset loss may not be as generalised in rural areas in Eastern Africa as some studies have claimed. The research calls for efforts to tackle gendered, age-related and generational inequalities in access to, and control of, assets and resources at key transition points in individuals' lifecourse, within a more supportive institutional environment. Efforts to prevent disinheritance in Tanzania and Uganda and other countries affected by the long-wave impacts of the HIV epidemic could usefully focus on legal support to challenge cases of disinheritance and asset loss, such as the promotion of will writing (Mendenhall et al., 2007), providing written evidence of property ownership and land titles, legal aid and advocacy (Cooper, 2010; 2012); rights-based social protection measures targeted towards the most vulnerable households (Richter, 2010), including caregiving children and youth, widow- and grandparent-headed households experiencing chronic poverty; advocacy and education about women's and children's inheritance rights at local and national levels; and opportunities for participation, peer support and collective mobilisation (Madoerin, 2008; Skovdal and Daniel, 2012). Such approaches appear to have considerable potential to tackle stigma and institutional and socio-cultural inequalities and build the capacities of widows and caregiving young people to safeguard their inheritance, to enhance their assets and to develop sustainable livelihoods that are resilient to chronic poverty over time. 


\section{Endnote}

1. Some of the arguments developed in this article are based on work originally commissioned by the Chronic Poverty Research Centre (CPRC) which is funded by UKaid from the UK Department for International Development (DFID) for the benefit of developing countries. The views expressed are not necessarily those of DFID. The CPRC gratefully acknowledges DFID's support.

\section{Acknowledgements}

I would like to thank all the young people, parents, relatives and NGO staff in Tanzania and Uganda who participated in the study. Special thanks to Caroline Day, University of Reading, who contributed to the original literature review and data analysis for the Chronic Poverty Research Centre (CPRC) Working Paper (Evans and Day, 2011). I am grateful to the Economic and Social Research Council (RES-000-22-1732-A), the Royal Geographical Society (with the Institute of British Geographers), the University of Reading and the Chronic Poverty Research Centre for funding the research. I also thank Dr. Sophie Bowlby, University of Reading and Prof. Saul Becker, University of Nottingham for their support. This article is dedicated to the late Emeritus Professor Rob Potter, University of Reading and founding Editor-in-Chief of this journal, who died in April 2014. 


\section{References}

Aliber, M. and Walker, C. 2006: The impact of HIV/AIDS on land rights: perspectives from Kenya. World Development 34(4),704-727.

Beegle, K., Filmer, D., Stokes, A. and Teirerova, L. 2010:Orphanhood and the living arrangements of children in sub-Saharan Africa. World Development 38(2),1727-1746.

Bird, K. and Higgins, K. 2011: Stopping the intergenerational transmission of poverty: research highlights and policy recommendations. Working Paper No. 214, CPRC.

Bird, K. and Espey, J. 2010: Power, patriarchy and land: examining women's land rights in Uganda and Rwanda. In S. Chant (Ed.) The International Handbook of Gender and Poverty. Cheltenham: Edward Elgar Publishing.

Bolt, V. and Bird, K. 2003: The intrahousehold disadvantages framework: a framework for the analysis of intra-household difference and inequality. Working Paper No. 32,CPRC.

Boyden, J. with Cooper, E. 2007:Questioning the Power of Resilience: Are Children Up To the Task of Disrupting the Transmission of Poverty?. Working Paper No. 73,CPRC.

Chambers, R., and Conway, G. 1992: Sustainable rural livelihoods: practical concepts for the 21st century. IDS Discussion Paper No.296, Brighton: IDS.

Cooper, E. 2012: Women and inheritance in Sub-Saharan Africa: what can change?. Development Policy Review 30(5),641-657.

Cooper, E. 2010:Inheritance and the intergenerational transmission of poverty in Sub-Saharan Africa: policy considerations. Working Paper 159,CPRC.

Deere, C. and Doss, C. (2006) 'Gender and the Distribution of Wealth in Developing Countries', Research Paper No 2006/115, Helsinki: United Nations University World Institute for Development Economics Research (UNU-WIDER). 
Drimie, S. 2003: HIV/Aids and Land: case studies from Kenya, Lesotho and South Africa. Development Southern Africa 20 (5),647-658.

Ellis, F. and Mdoe, N. 2003: Livelihoods and rural poverty reduction in Tanzania. World Development 31(8),1367-1384.

Evans, R. 2011:'We are managing our own lives'...: life transitions and care in sibling-headed households affected by AIDS in Tanzania and Uganda. Area 43(4),384-396.

Evans, R. and Becker, S. 2009: Children Caring for Parents with HIV and AIDS: Global Issues and Policy Responses. Bristol: The Policy Press.

Evans, R. and Day, C. 2011: Inheritance, poverty and HIV/AIDS: experiences of widows and orphaned youth heading households in Tanzania and Uganda. CPRC Working Paper 185/ Manchester: Chronic Poverty Research Centre.

Harper, C., Marcus, R. and Moore, K. 2003: Enduring poverty and the conditions of childhood: lifecourse and intergenerational poverty transmissions. World Development 31(3),535-554.

Hopkins, P. and Pain, R. 2007: Geographies of age: thinking relationally. Area 39(3),287-294. Hulme, D. and Shepherd, A. 2003: Conceptualising Chronic Poverty. World Development 31(3),403-423.

Izumi, K. 2007: Gender-based violence and property grabbing in Africa: a denial of women's liberty and security. Gender and Development 15(1),11-23.

Joireman, S. 2008: The mystery of capital formation in Sub-Saharan Africa: women, property rights and customary law. World Development 36(7),1233-1246.

Kabeer, N. 2000: Inter-generational contracts, demographic transitions and the "quantity-quality" trade-off: parents, children and investing in the future. Journal of International Development 12(4),463-482. vulnerability and resilience of widows and caregiving children and youth in Tanzania and Uganda, Progress in Development Studies. 
de Klerk, J. 2011: Being old in times of AIDS: aging, caring and relating in northwest Tanzania. PhD thesis, Amsterdam Institute for Social Science Research (AISSR).

Madoerin, K. 2008:Mobilising Children and Youth into Their Own Child-and Youth-led

Organisations. Johannesburg, South Africa, Regional Psychosocial Support Initiative.

Mendenhall, E., Muzizi, L., Stephenson, R., Chomba, E., Ahmed, Y., Haworth, A. and Allen, S. 2007:Property grabbing and will writing in Lusaka, Zambia: an examination of wills of HIVinfected co-habiting couples. AIDS Care 19(3),369-374.

Muyinda, H., Seeley, J., Pickering, H. and Barton, T. 1997:Social aspects of AIDS-related stigma in rural Uganda. Health and Place 3(3),143-147.

Nyambedha, E., Wandibba, S. and Aagaard-Hansen, J. 2003:Changing patterns of orphan care due to the HIV epidemic in Western Kenya. Social Science and Medicine 57(2),301-11.

Odgaard, R. 2002:Scrambling for Land in Tanzania: Process of formalisation and legitimisation of land rights. European Journal of Development Research 14(2),71-88.

Ogden, J. and Nyblade, L. 2005:Common at its Core: HIV-related Stigma Across Contexts. International Center for Research on Women (ICRW), Washington.

Oleke, C., Blystad, A. and Rekdal, O. 2005:"When the obvious brother is not there”: political and cultural contexts of the orphan challenge in northern Uganda, Social Science and Medicine 61 (12),2628-38.

Omari, C. and Mbilinyi, S.1997:African Values and Child Rights: Some Cases From Tanzania, Dar es Salaam: Dar es Salaam University Press.

Parker R. and Aggleton, P. 2007:HIV- and AIDS-related stigma and discrimination: a conceptual framework and implications for action. In R. Parker and P. Aggleton (Eds.), Culture, Society and Sexuality: A Reader. London: Routledge,443-458. vulnerability and resilience of widows and caregiving children and youth in Tanzania and Uganda, Progress in Development Studies. 
Peterman, A. 2012:Widowhood and asset inheritance in Sub-Saharan Africa: empirical evidence from 15 countries. Development Policy Review, 30(5),543-571.

Radcliffe, S. 2006:Culture in development thinking: geographies, actors and paradigms. In S. Radcliffe (Ed.), Culture and Development in a Globalizing World: Geographies, Actors and Paradigms. London and New York: Routledge,1-29.

Richter, L. 2010:Social cash transfers to support children and families affected by HIV/AIDS. Vulnerable Children and Youth Studies No. S1 5,81-91.

Ringsted, M. 2008:Collisions in life-courses: teenage motherhood and generational relations in north-east Tanzania. In Alber, E., Van de Geest, S. and Reynolds Whyte, S. (eds.) Generations in Africa. Berlin: Lit Verlag,357-380.

Rose, L. 2007:Children's Property and Inheritance Rights, HIV and AIDS and Social Protection in Southern and Eastern Africa. HIV/AIDS Programme Working Paper 2, Rome: Food and Agriculture Organization of the United Nations.

Roura, M., Urassa, M, Busza, J., Mbata,D., Wringe,A. and Zaba, B. 2009: Scaling up stigma? The effects of antiretroviral rollout on stigma and HIV testing. Early evidence from rural Tanzania. Sexually Transmitted Infections 85:308-312.

Samuels, F. and Wells, J. 2009:The loss of the middle ground: the impact of crises and HIV and AIDS on "skipped-generation" households. ODI Project Briefing No. 33, November 2009. London: Overseas Development Institute.

Seeley, J. 2008:The intergenerational transmission of poverty during the AIDS epidemic in Uganda. Working Paper No.110. Manchester: CPRC.

Seeley, J. 2012: The Changing Relationships of Co-wives Over Time in Rural Southern Uganda, Journal of Development Studies, 2012, 48(1),68-80. vulnerability and resilience of widows and caregiving children and youth in Tanzania and Uganda, Progress in Development Studies. 
Skovdal, M. 2011: Examining the trajectories of children providing care for adults in rural Kenya: implications for service delivery. Children and Youth Services Review 33:1262-1269.

Skovdal, M. and Daniel, M.2012:Resilience through participation and coping-enabling social environments: the case of HIV-affected children in sub-Saharan Africa. African Journal of AIDS Research,11(3),153-164.

Stambach, A. 2000:Lessons from Mount Kilimanjaro. Schooling, Community and Gender in East Africa. London: Routledge.

Tanzania Commission for AIDS (TACAIDS), National Bureau of Statistics (NBS) and ORC Macro 2005: Tanzania HIV/AIDS indicator survey 2003-04. Calverton, MD: Tanzania Commission for AIDS, National Bureau of Statistics and ORC Macro.

Tripp, A. 2004: Women's movements, customary law and land rights in Africa: the case of Uganda. African Studies Quarterly, 7(4).

Uganda Bureau of Statistics (UBOS) 2006: Uganda National Household Survey 2005/06: report on the socio-economic module. Kampala: Uganda Bureau of Statistics.

UNAIDS, 2010: Global Report: UNAIDS Report on the Global AIDS Epidemic 2010. New York: Joint United Nations Programme on HIV/AIDS (UNAIDS).

UNAIDS, 2013: Global Report: UNAIDS Report on the Global AIDS Epidemic 2012. New York: Joint United Nations Programme on HIV/AIDS (UNAIDS).

United Nations Children's Fund (UNICEF)2006: The State of the World's Children 2007. Women and Children: the double dividend of gender equality. New York: United Nations Children's Fund. Walsh, J. 2005: Women's property rights violations and HIV/AIDS in Africa. Peace Review: a Journal of Social Justice. 17,189-195. vulnerability and resilience of widows and caregiving children and youth in Tanzania and Uganda, Progress in Development Studies. 
Whitehead, A. and Tsikata, D. 2003: Policy Discourses on Women's Land Rights in Sub-Saharan Africa: The Implications of the Re-turn to the Customary. Journal of Agrarian Change 3(1 and 2),67-112.

Wood, K., Chase, E. and Aggleton, P. 2006:"Telling the truth is the best thing”: teenage orphans experiences of parental AIDS-related illness and bereavement in Zimbabwe. Social Science and Medicine 63(7),1923-33. vulnerability and resilience of widows and caregiving children and youth in Tanzania and Uganda, Progress in Development Studies. 